\title{
MENCIPTAKAN LAYANAN PAUD YANG PRIMA MELALUI PENERAPAN PRAKTIK ACTIVITY BASED COSTING
}

\author{
Novan Ardy Wiyani $\left.{ }^{*}\right)$ \\ ${ }^{1}$ Fakultas Tarbiyah dan IImu Keguruan, IAIN Purwokerto, Purwokerto 53126, Indonesia
}

*)E-mail: fenomenajiwa@gmail.com

\begin{abstract}
Abstrak
Masalah keterbatasan anggaran dalam memenuhi kebutuhan konsumen di lembaga PAUD dapat diatasi dengan menerapkan praktik Activity Based Costing (ABC). Penelitian ini merupakan penelitian kualitatif yang bertujuan untuk mendeskripsikan langkah penerapan praktik $A B C$ sebagai upaya untuk mengoptimalkan penyelenggaraan Pendidikan Anak Usia Dini (PAUD) di RA Masyithoh. RA Masyithoh dipilih dengan pertimbangan lembaga ini telah menerapkan praktik $A B C$ dalam menciptakan layanan PAUD yang prima. Data dalam penelitian ini dikumpulkan dengan cara wawancara, observasi, dan dokumentasi kemudian dianalisis menggunakan teknik analisis data model Miles dan Huberman. Hasil penelitian menunjukkan ada lima langkah yang dilakukan dalam menciptakan layanan PAUD yang prima melalui praktik ABC. Pertama, mengidentifikasikan, mendefinisikan, serta mengelompokkan aktivitas. Kedua, melakukan penelusuran secara langsung terhadap aktivitas dan objek biaya. Ketiga, membebankan biaya ke kelompok biaya aktivitas. Keempat, menghitung tarif aktivitas. Kelima, menyusunan laporan. Kelima langkah tersebut mampu menciptakan layanan prima dan meningkatkan kepuasan konsumen dengan indikasi terjadi peningkatan jumlah siswa di setiap tahunnya, anggaran yang dibutuhkan untuk melaksanakan kegiatan PAUD dapat terpenuhi, dan secara kelembagaan RA Masyithoh mengalami perkembangan dengan didirikannya Taman Penitipan Anak dan Kelompok Bermain.
\end{abstract}

Kata Kunci: kepuasan konsumen, kualitas layanan, PAUD, praktik ABC

\section{Creating Excellent Services in Early Childhood Education through the Implementation of Activity Based Costing}

\begin{abstract}
The problem of budget limitations in meeting the needs of consumers in early childhood education institutions can be overcome by applying the Activity Based Costing (ABC) practice. This research is a qualitative research that has aimed to describe the steps of applying $A B C$ practices as an effort to optimize the implementation of Early Childhood Education (ECE) in RA Masyithoh. RA Masyithoh was chosen with the consideration that this institution has implemented ABC practices in creating excellent PAUD services. The data in this study were collected by interview, observation, and documentation then analyzed using the Miles and Huberman data analysis technique. The results showed there were five steps taken in creating excellent PAUD services through the practice of Activity Based Costing (ABC). First, identify, define, and classify activities. Second, do a direct search of activities and cost objects. Third, it imposes costs to the activity cost group. Fourth, calculate activity rates. Fifth, compile the report. The five steps are able to create excellent service and increase customer satisfaction with an indication of an increase in the number of students each year, the budget needed to carry out PAUD activities can be met, and institutionally RA Masyithoh experiences growth with the establishment of a Day Care and Play Group.
\end{abstract}

Keyword: ABC practice, consumer satisfaction, ECE, quality of service

\section{PENDAHULUAN}

Perkembangan pendidikan di Indonesia akan sangat menentukan perkembangan pembangunan nasional. Hal ini disebabkan karena melalui pendidikan yang bermutu, akan tercipta sumber daya manusia (SDM) yang berkualitas serta memiliki daya saing tinggi (Sukendar, Usman, \& Jabar, 2019). Mutu SDM suatu negara tercermin dalam penyelenggaraan layanan pendidikan mulai dari jenjang Pendidikan Anak Usia Dini (PAUD) hingga jenjang perguruan tinggi. Berbagai upaya dilakukan oleh pemerintah untuk menghasilkan penyelenggaraan layanan PAUD yang bermutu. Satu upaya yang dilakukan adalah dengan menetapkan standar PAUD secara nasional sebagaimana yang diatur dalam Peraturan Menteri Pendidikan dan Kebudayaan (Permendikbud) Nomor 137 Tahun 2014 tentang Standar Nasional PAUD (Mulyasa, 2017). Apabila standar dalam 
Permendikbud tersebut mampu diterapkan maka akan menghasilkan layanan PAUD yang bermutu. Lembaga PAUD yang bermutu memiliki peranan yang signifikan dalam pencapaian tumbuh-kembang anak yang optimal (Mukti \& Hendrawan, 2018).

Layanan PAUD yang bermutu dapat direalisasikan melalui pengelolaan penyelenggaraan PAUD yang optimal. Namun, saat ini masih banyak ditemukan lembaga PAUD yang mengalami kesulitan dalam menyelenggarakan PAUD yang optimal. Penyebabnya adalah karena keterbatasan kompetensi manajerial yang dimiliki oleh pengelola PAUD. Apabila Layanan PAUD yang diberikan tidak optimal maka aktivitas belajar dan bermain di PAUD juga akan kurang maksimal. Sistem pengajaran juga akan cenderung mengabaikan aspek kreativitas dan inovasi (Risaldy, 2014).

Salah satu Lembaga yang menyelenggarakan PAUD adalah Raudhatul Athfal (RA). RA merupakan lembaga PAUD formal di bawah naungan Kementerian Agama Republik Indonesia. RA menjadi salah satu lembaga yang bertanggung jawab untuk mengoptimalkan tumbuh kembang anak usia dini di berbagai aspek perkembangan. Melalui PAUD, anak diharapkan memiliki kesiapan untuk melanjutkan ke jenjang pendidikan yang lebih tinggi (Pardede, Supena, \& Fahrurozi., 2018). Semua kemampuan yang dimiliki oleh anak dicapai melalui kegiatan pembelajaran yang bermutu. RA pun dituntut untuk mampu menyelenggarakan layanan PAUD yang bermutu.

Mutu merupakan segala sesuatu yang mampu memenuhi keinginan atau kebutuhan konsumen (meeting the needs of customers) (Mulyasana, 2015). Bagi seorang pemimpin, mengelola lembaga pendidikan agar bermutu merupakan hal yang sulit. Mutu yang dihasilkan oleh suatu lembaga pendidikan dapat memenuhi kebutuhan konsumen (Simangunsong, 2019). Oleh karenanya, layanan pendidikan yang diselenggarakan oleh lembaga PAUD menjadikan keinginan dan kebutuhan konsumen (wali murid) sebagai target layanan. Ketercapaian keinginan dan kebutuhan akan mengantarkan pada kepuasan konsumen (Supriyanto, 2015). Ketidakpuasan konsumen biasanya ditunjukkan dalam bentuk perilaku komplain (Aisyiyah, Hartoyo, \& Krisnatuti, 2019). Dengan demikian, pencapaian kepuasan konsumen yang didapat oleh suatu lembaga akan dapat mengurangi komplain dari konsumen. Komplain tersebut tidak dihilangkan tetapi dikurangi karena suatu lembaga tetap membutuhkan komplain. Melalui komplain, pelaku usaha dapat memperbaiki kekurangannya dan dapat meningkatkan kualitas dan memberikan kepuasan bagi konsumen (Wandani \& Simanjuntak, 2019).

Seorang konsumen yang puas adalah konsumen yang dapat merasakan nilai dari penyedia jasa. Nilai ini bisa berasal dari pelayanan atau sesuatu yang bersifat emosional. Jika konsumen mengatakan bahwa nilai adalah layanan yang berkualitas, maka kepuasan terjadi jika konsumen mendapatkan layanan yang prima. Penting untuk dilakukan upaya perbaikan yang komprehensif dan berkelanjutan untuk menghasilkan layanan yang prima oleh pihak penyedia jasa layanan (Miswanto \& Angelia, 2017). RA merupakan lembaga PAUD yang memberikan jasa kepada para orang tua sesuai dengan keinginan dan kebutuhan mereka. Pihak RA sebagai penyedia jasa layanan PAUD diharapkan dapat menyelenggarakan layanan PAUD yang bermutu, yaitu layanan PAUD yang mampu memenuhi keinginan dan kebutuhan wali murid sebagai konsumen eksternalnya (external customers). Layanan PAUD yang bermutu dapat dihasilkan ketika pihak RA mampu menciptakan layanan prima (service excellence) bagi para wali muridnya (Zulkarnain dan Sumarsono, 2018). Layanan prima pada dasarnya merupakan upaya memberikan program yang terbaik atas dasar kepedulian kepada para konsumen oleh suatu organisasi maupun bidang usaha.

Tujuan penciptaan layanan prima adalah untuk memuaskan para konsumen sehingga kebutuhannya terpenuhi. Para peneliti menyakini bahwa organisasi yang mampu menyelenggarakan layanannya yang berorientasi pada konsumen akan mendapatkan manfaat sosial dan psikologis yang baik dari para konsumennya (Yuniawan, 2011). Sedangkan manfaat yang didapat dari terciptanya layanan yang prima oleh suatu lembaga adalah para konsumen akan senantiasa memilih untuk mendapatkan layanan. Konsumen juga akan memberikan rekomendasi kepada pihak lain untuk samasama menggunakan layanan jasa tersebut. (Sharma \& Nandi, 2018). Manfaat lainnya adalah layanan prima mampu memenuhi standar mutu yang telah ditentukan (Rangkuti, 2017). Jadi layanan prima dalam penyelenggaraan PAUD dihasilkan ketika dapat memenuhi standar nasional PAUD sebagaimana diatur dalam Permendikbud Nomor 137 tahun 2014. 
Dalam perspektif pendidikan, lembaga pendidikan pada hakikatnya ada untuk memberikan pelayanan kepada masyarakat sebagai konsumen pendidikan. Ketika menjalankan fungsinya, lembaga pendidikan memiliki karakteristik yang berbeda dengan organisasi bisnis, tetapi dalam melaksanakan misi, tujuan dan programnya memiliki prinsip efisiensi, efektivitas, dan memosisikan masyarakat sebagai pihak yang harus dilayani secara optimal. Layanan kepada konsumen pendidikan pada dasarnya adalah hak konsumen yang memiliki prinsip kesederhanaan, kejelasan, kepastian waktu, akurasi, keamanan, kenyamanan, tanggungjawab, kelengkapan sarana serta prasarana, kemudahan akses, kedisiplinan, kesopanan, dan keramahan (Oji, 2015).

Penerapan metode $A B C$ pada suatu lembaga dapat menghasilkan pendidikan yang bermutu. Selain itu pengelolaan keuangan juga berlangsung efektif dan efisien karena memiliki relevansi dengan berbagai aktivitas pendidikan yang telah ditentukan (Fattah, 2017). Sementara itu, lembaga yang belum menerapkan metode ABC mendapatkan hambatan dalam menyelenggarakan layanan pendidikannya sehingga belum mampu menghasilkan pendidikan yang bermutu. Hambatan yang dihadapi tersebut antara lain berupa ditemukannya ketidaksesuaian antara ketersediaan anggaran dengan banyaknya kegiatan yang telah ditentukan, kegiatankegiatan yang telah dirumuskan belum sesuai dengan kebutuhan dan harapan konsumen, serta penggunaan anggaran kegiatan menjadi kurang terkendali (Fattah dan Gautama, 2017). Hasil penelitian tersebut menunjukkan bahwa layanan PAUD yang prima dapat diberikan melalui penerapan praktik $A B C$.

Dalam konteks penyelenggaraan layanan PAUD oleh RA, maka layanan prima bertitik tolak pada upaya kepala RA, guru, dan staf untuk memberikan layanan terbaiknya sebagai wujud kepeduliannya terhadap wali murid agar keinginan dan kebutuhan wali murid terpenuhi. Masyarakat pada masa sekarang ini masih memandang RA sebelah mata dan lebih memilih TK sebagai lembaga PAUD tempat putra-putrinya belajar. Masyarakat berpendapat bahwa layanan yang diselenggarakan oleh TK lebih baik daripada yang diselenggarakan oleh RA, padahal pendapat tersebut tidaklah benar (Adiyanto, 2019). RA juga mampu menyelenggarakan layanan PAUD yang prima. Hal itu telah dilakukan oleh RA Masyithoh dengan menciptakan layanan PAUD yang prima melalui penerapan praktik Activity Based Costing (Maryani, 2019).

Praktik ABC di RA merupakan suatu bentuk inovasi layanan di bidang PAUD karena lazimnya $A B C$ dilaksanakan di perusahaanperusahaan. Praktik ABC dilakukan dengan enam tahapan. Pertama, mengidentifikasi, mendefinisikan, dan mengelompokkan aktivitas. Kedua, penelusuran langsung ke aktivitas dan objek biaya. Ketiga, membebankan biaya ke kelompok biaya aktivitas. Keempat, menghitung tarif aktivitas. Kelima, membebankan biaya ke objek biaya dengan menggunakan tarif aktivitas dan ukuran aktivitas. Keenam, menyusun laporan manajemen (Fattah, 2017).

Praktik $A B C$ di $R A$ telah menjadi suatu bentuk inovasi layanan di bidang PAUD mengingat sebagian besar lembaga PAUD masih menggunakan metode pembiayaan tradisional dalam praktik manajemen pembiayaan PAUD. Inovasi layanan pada dasarnya merupakan suatu konsep layanan yang dipraktikkan untuk mendapatkan apresiasi dari konsumen (Hariandja, Simatupang, Nasution, \& Larso, 2014). Fokus utama praktik $A B C$ adalah kegiatan atau aktivitas. Ada dua prinsip yang melandasi $A B C$ yaitu biaya yang dibutuhkan untuk melaksanakan suatu aktivitas harus sesuai dengan kebutuhan pada aktivitas tersebut dan ketika kebutuhan pada suatu aktivitas dapat terpenuhi maka aktivitas tersebut dapat dikelola dengan baik. Praktik $A B C$ yang fokus pada kegiatan atau aktivitas dapat mengarah pada penciptaan layanan prima pada suatu organisasi (Fattah, 2016). Model ABC disajikan pada Gambar 1. Model ABC menunjukkan bahwa mekanisme dalam praktik $A B C$ diawali oleh kerja sumber daya lembaga dalam menentukan aktivitas. Setiap aktivitas memiliki besaran biaya dan ada penyebab mengapa biaya tersebut harus dipenuhi. Untuk memenuhinya maka dilakukan pengelolaan (manajemen) biaya melalui enam tahapan dalam implementasi praktik ABC.

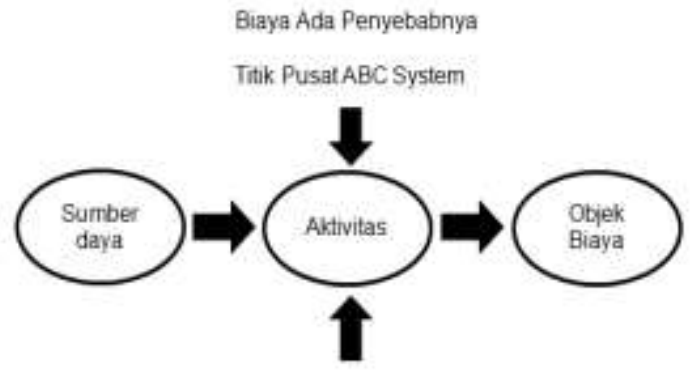

Penyebab Biaya dapat Dikeiola melalui Activity Based Costing (ABC)

Gambar 1 Model Activity Based Costing (Fattah, 2017) 
Setiap lembaga harus mampu memberikan layanan yang prima. Alasannya, layanan prima menentukan kepuasan konsumen. Beberapa penelitian telah membuktikan hal tersebut. Hasil penelitian Riyadi, Hermawan, dan Sumarwan (2015) menunjukkan bahwa kualitas pelayanan berpengaruh signifikan terhadap kepuasan konsumen. $\mathrm{Hal}$ ini menunjukkan bahwa semakin baik kualitas pelayanan maka semakin besar kepuasan konsumen. Kepuasan konsumen ini merupakan hal yang penting bagi keberlanjutan usaha. Perilaku konsumen, kepuasan konsumen, dan loyalitas konsumen merupakan aspek penting yang menentukan keberlanjutan sebuah usaha, khususnya pada sebuah usaha yang baru dan mempunyai jumlah pesaing yang cukup banyak (Ramdhani, Daryanto, \& Rifin, 2015). Oleh karenanya, untuk membuat konsumen memiliki kepuasan dan juga loyalitan yang baik maka lembaga harus mampu memberikan pelayanan yang prima.

Berdasarkan pemaparan tersebut, keberhasilan lembaga PAUD dalam mencapai tujuan bergantung pada kemampuan PAUD dalam memberikan layanan. Layanan yang diberikan sebaiknya merupakan layanan yang prima. Salah satu model yang dapat digunakan untuk mengoptimalkan peneyelenggaraan PAUD adalah model Activity Based Costing (ABC). Penelitian ini bertujuan untuk mendeskripsikan langkah-langkah penerapan praktik $A B C$ sebagai upaya untuk mengoptimalkan penyelenggaraan PAUD.

\section{METODE}

Penelitian ini menggunakan pendekatan kualitatif dengan jenis penelitian fenomenologi. Penelitian fenomenologi merupakan penelitian yang didasari oleh pandangan berpikir yang menekankan pada pengalaman-pengalaman manusia sebagai subjek penelitian (Moleong, 2012). Pendekatan dan jenis penelitian tersebut dipilih karena dalam penelitian ini tidak ada rekayasa pada subjek dan objek kajian penelitian. Penelitian ini dilakukan dari bulan Januari hingga bulan Oktober tahun 2019.

Penelitian dilaksanakan di RA Masyithoh Mertasinga Cilacap. Pemilihan sampel penelitian dilakukan dengan teknik purposive. Teknik purposive dapat digunakan pada penelitian dengan subjek yang memiliki kekhasan yang tidak ditemukan pada subjek penelitian lainnya (Sugiyono, 2010). RA Masyithoh Mertasinga Cilacap dipilih sebagai sampel penelitian karena menjadi satu-satunya RA di Kabupaten Cilacap yang menggunakan metode Activity Based Costing (ABC) dalam pengelolaan pembiayaan PAUD.

Data pada penelitian ini dikumpulkan dengan wawancara, observasi, dan dokumentasi. Wawancara dilakukan dengan pengawas RA, kepala RA, guru RA, bendahara, dan komite sekolah. Observasi dilakukan untuk mengamati jalannya layanan PAUD. Dokumen-dokumen yang dikaji yaitu Rencana Anggaran Belanja (RAB), buku kas, buku administrasi keuangan bagi wali murid, laporan keuangan bulanan, dan laporan keuangan tahunan.

Uji validitas data dilakukan dengan menggunakan teknik triangulasi sumber data, yaitu melalui crosh check terhadap data-data yang berasal dari tiga sumber, yaitu kepala RA, guru, dan bendahara (Moleong, 2012). Data kemudian dianalisis menggunakan teknik analisis model Miles dan Huberman. Pada teknik ini, data dianalisis secara bertahap dimulai dengan mereduksi data, menyajikan data, dan memverifikasi data (Sugiyono, 2010). Tahap reduksi data dilakukan dengan cara memilah data dari sumber data yang memiliki relevansi dengan tujuan penelitian. Tahap penyajian data dilakukan dengan cara menguraikan data teks yang bersifat naratif. Tahap verifikasi data dilakukan dengan cara menarik kesimpulan dan membuat verifikasi untuk menjawab rumusan masalah penelitian (Sugiyono, 2010).

\section{HASIL}

\section{Tujuan Menciptakan Layanan Prima}

RA Masyithoh Mertasinga Cilacap telah menggunakan Activity Based Costing (ABC) sejak tahun 2005. Ada tiga hal yang melatarbelakangi Lembaga ini dalam menggunakan ABC. Pertama, adanya kesadaran pada stakeholders PAUD di RA Masyithoh Mertasinga Cilacap bahwa layanan prima dalam penyelenggaraan PAUD diciptakan dengan kemampuan pihak RA dalam menyelenggarakan aktivitas-aktivitas PAUD yang sesuai dengan keinginan dan kebutuhan wali murid. Kedua, aktivitas-aktivitas tersebut dapat dilaksanakan secara efektif dan efisien ketika pihak RA memiliki anggaran atau pembiayaan pendidikan yang mencukupi. Ketiga, adanya kesadaran bahwa layanan PAUD harus diselenggarakan dengan prinsip akuntabilitas dan responsibilitas.

Berdasarkan hasil penelitian dapat diketahui bahwa ada tiga tujuan menerapkan layanan PAUD yang prima dengan praktik $A B C$ 
(Maryani, 2019). Pertama, untuk menjamin ketersediaan anggaran dalam penyelenggaraan layanan PAUD. Kedua, untuk meminimalisir keluhan dari wali murid terhadap penyelenggaraan layanan PAUD. Ketiga, untuk mendapatkan kepercayaan dari wali murid yang dapat berimplikasi pada peningkatan jumlah peserta didik baru. Berdasarkan hasil dokumentasi dapat diketahui bahwa sejak diterapkannya praktik $A B C$ oleh pihak RA Masyithoh Mertasinga Cilacap perolehan peserta didik baru semakin meningkat (Gambar 2). Gambar 2 memperlihatkan terjadi peningkatan jumlah peserta didik setelah RA Masyithoh Mertasinga Cilacap menerapkan praktik ABC. Pada tahun pelajaran 2016/2017 terdapat 103 peserta didik, jumlah ini mengalami penurunan menjadi 98 peserta didik pada tahun pelajaran 2017/2018, kembali mengalami penambahan menjadi 108 peserta didik pada tahun 2018/2019 dan 135 peserta didik pada tahun pelajaran 2019/2020 (Maryani, 2019).

\section{Langkah Menciptakan Layanan Prima}

Hasil penelitian menunjukkan bahwa ada lima langkah yang dilakukan dalam menciptakan layanan prima dalam penyelenggaraan PAUD melalui praktik $A B C$ di RA Masyithoh Mertasinga Cilacap (Maryani, 2019). Langkah tersebut adalah mengidentifikasikan, mendefinisikan, serta mengelompokkan aktivitas; melakukan penelusuran secara langsung terhadap aktivitas dan objek biaya; membebankan biaya ke kelompok biaya aktivitas; menghitung tarif aktivitas; dan menyusunan laporan.

Langkah pertama yang dilakukan adalah mengidentifikasikan, mendefinisikan, serta mengelompokkan aktivitas. Ada tiga kegiatan yang dilakukan dalam langkah pertama, yaitu (1) mengidentifikasi keinginan dan kebutuhan wali murid; (2) mengidentifikasi keluhankeluhan dalam penyelenggaraan layanan PAUD dari wali murid; (3) mengidentifikasi kegiatan-kegiatan PAUD untuk memenuhi keinginan dan kebutuhan serta keluhan dari wali murid (Maryani, 2019).

Identifikasi keinginan wali murid dilakukan dengan cara menampung usulan dari wali murid baik secara formal dalam rapat-rapat, secara non formal ketika berbincang di lingkungan RA, dan melalui pemanfaatan grup WhatsApp wali murid. Cara lain yang digunakan untuk mengidentifikasi keinginan wali murid adalah dengan melakukan kerjasama dengan komite sekolah untuk menyusun daftar keinginan wali murid. Hasil inventaris menunjukkan terdapat dua keinginan dari wali murid, yaitu: (1) wali murid menginginkan agar anak-anak-anaknya bisa mendapatkan layanan PAUD secara maksimal agar tumbuh-kembang anak bisa berlangsung optimal; (2) wali murid ingin agar anak merasa nyaman dalam kegiatan belajar. Kenyamanan belajar tersebut menjadikan anak memiliki motivasi belajar yang tinggi. Harapannya dengan motivasi belajar yang tinggi kemudian anak bisa mencapai hasil belajar yang maksimal. Pihak RA Masyithoh Mertasinga Cilacap berusaha memenuhi keinginan wali murid karena memang pihak RA memiliki keyakinan bahwa eksistensi RA akan sangat dipengaruhi oleh kemampuan pihak RA dalam memenuhi keinginan wali murid. Dengan kata lain, maju atau mundurnya RA akan sangat dipengaruhi oleh kemampuan RA dalam melayani wali murid sesuai dengan keinginan (Maryani, 2019).

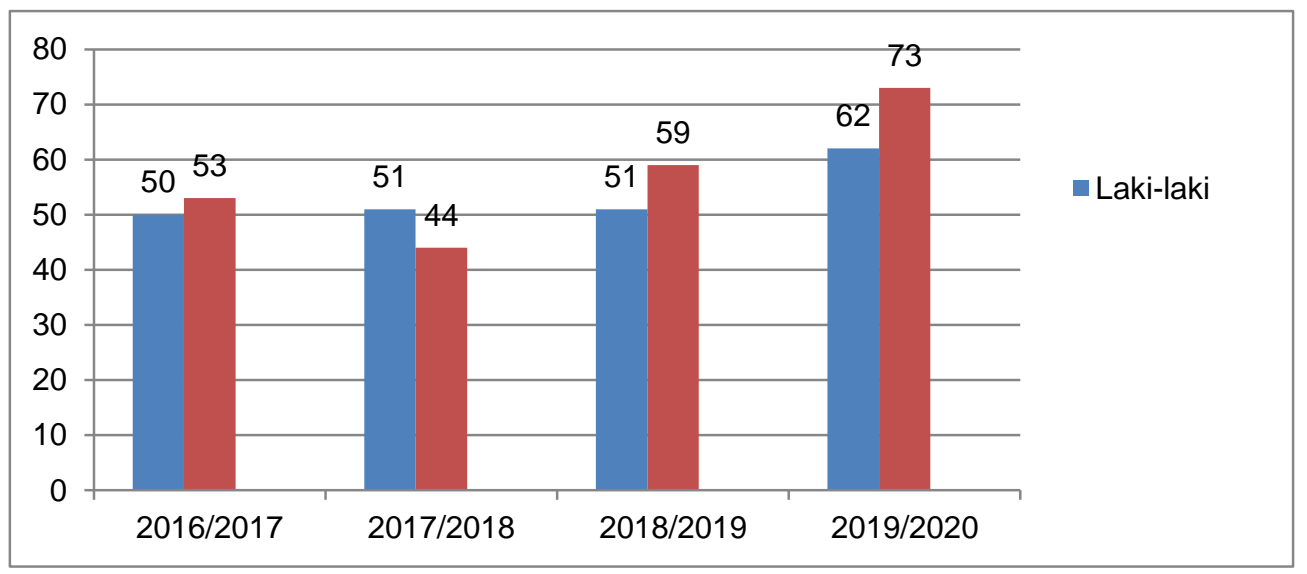

Gambar 2 Jumlah peserta didik pada empat tahun terakhir di RA Masyithoh Mertasinga Cilacap (Maryani, 2019b) 
Kemudian cara yang digunakan untuk mengidentifikasi kebutuhan wali murid adalah dengan menyediakan kotak saran, memberi kebebasan mengutarakan apa yang dibutuhkan saat pertemuan wali murid ataupun saat berkomunikasi secara nonformal baik di lingkungan RA maupun di grup jejaring sosial. Pihak RA Masyithoh Mertasinga Cilacap mengungkapkan bahwa hal yang dibutuhkan oleh wali murid dari layanan PAUD yang diselenggarakan yaitu informasi tentang kegiatan anak serta informasi tentang hasil belajar anak dan masalah-masalah yang dihadapi oleh anak ketika belajar. Wali murid membutuhkan hal itu untuk mempersiapkan waktu dan biaya serta strategi dalam menyiapkan kebutuhan fisik serta kebutuhan psikis anak. Pihak RA Masyithoh Mertasinga Cilacap memenuhinya dengan memberi kalender pendidikan RA Masyithoh dan jadwal kegiatan keseharian anak (Maryani, 2019).

Sementara itu identifikasi keluhan dilakukan dengan menyediakan kotak saran dan memberi keluasan menceritakan keluhan melalui WhatsApp. Hal-hal yang dikeluhkan oleh wali murid yaitu tentang masalah administrasi yang terkadang merepotkan, pelayanan guru yang kurang sesuai dengan harapan, kenakalan anak, serta keterbatasan sarana dan prasarana. Wali murid merasa kurang nyaman dengan masalah-masalah dan keadaankeadaan tersebut.

Pihak RA Masyithoh Mertasinga Cilacap mengidentifikasi kegiatan-kegiatan PAUD untuk memenuhi keinginan dan kebutuhan serta keluhan dari wali murid. Kegiatan-kegiatan yang telah terindentifikasi yaitu: kegiatan pertemuan wali murid, pengajian, parenting, serta kegiatan pembelajaran dan pembiasaan sesuai dengan kurikulum 2013. Pihak RA yakin bahwa kegiatan-kegiatan tersebut dapat menjawab keinginan, kebutuhan, dan keluhankeluhan dari wali murid. Untuk melaksanakan kegiatan-kegiatan tersebut hal-hal yang dibutuhkan yaitu tempat, narasumber, dan biaya (Maryani, 2019).

Langkah kedua, melakukan penelusuran secara langsung terhadap aktivitas dan objek biaya (Maryani, 2019). Ada tiga kegiatan yang dilakukan dalam langkah kedua, yaitu: (1) mengidentifikasi setiap kebutuhan yang dibutuhkan dalam pelaksanaan setiap kegiatan PAUD; (2) mengidentifikasi besaran biaya di setiap kegiatan PAUD; dan (3) menyusun draf Rencana Anggaran Belanja (RAB) kegiatan PAUD (Maryani, 2019).
Kebutuhan-kebutuhan dalam pelaksanaan kegiatan PAUD yang telah dirumuskan antara lain biaya atau anggaran, kegiatan pelatihan untuk pengembangan kompetensi guru, serta sarana dan prasarana pendidikan yang sesuai dengan standar dan keinginan wali murid. Perkiraan atau estimasi biaya untuk pemenuhan kebutuhan-kebutuhan tersebut adalah Rp1.500.000,00 per bulan. Sumber dana untuk melaksanakan kegiatan PAUD bersumber dari SPP anak.

Berdasarkan perkiraan biaya serta sumber pembiayaan kemudian disusunlah draf RAB. Draf RAB disusun di awal tahun pelajaran (Maryani, 2019a). Pada draf RAB ditetapkan perkiraan anggaran yang dibutuhkan di setiap bulan karena pada setiap bulannya akan ada kegiatan-kegiatan yang berbeda-beda. Pihakpihak yang terlibat dalam penyusunan draf RAB antara lain kepala RA, guru, pengurus, dan komite sekolah. Stakeholders tersebut terlibat dalam penyusunan draf $R A B$ dan memastikan besaran anggaran yang dibutuhkan untuk melaksanakan setiap kegiatan.

Lebih lanjut, kegiatan yang bersifat rutin untuk dilaksanakan pada setiap tahun pelajaran memudahkan pihak RA dalam menyusun draf RAB. Dari kegiatan-kegiatan rutin itu pihak RA dapat memprediksi besaran anggaran setiap kegiatan untuk tahun pelajaran sekarang berdasarkan besaran anggaran di tahun pelajaran sebelumnya. Sementara itu, kegiatankegiatan insidental menjadi hal yang menyulitkan pihak RA dalam menyusun draf RAB. Ini karena besaran anggaran tersebut tidak bisa diprediksi. Kegiatan-kegiatan insidental berupa kegiatan-kegiatan sosial.

Langkah ketiga, membebankan biaya ke kelompok biaya aktivitas. Berdasarkan hasil penelitian dapat diketahui bahwa kegiatan yang dilakukan pada langkah ketiga antara lain: (1) mensosialisasikan draf RAB kegiatan PAUD; (2) membahas draf RAB kegiatan PAUD bersama dengan komite sekolah; dan (3) mensosialisasikan RAB kegiatan PAUD (Maryani, 2019).

Kegiatan sosialisasi draf RAB dilakukan dengan melampirkan draf RAB pada formulir pendaftaran peserta didik baru. Draf RAB tersebut kemudian dijadikan pula sebagai pertimbangan oleh wali murid untuk menyekolahkan anaknya di RA Masyithoh Mertasinga Cilacap. Kemudian secara keseluruhan draf RAB disampaikan pada rapat perdana dengan wali murid dan komite sekolah. Pihak-pihak yang diundang dalam rapat 
tersebut antara lain wali murid, komite sekolah, serta pengurus. Semua stakeholders turut mensukseskan sosialisasi dengan memberikan masukan-masukan terhadap hal-hal yang dianggap lemah pada draf RAB.

Biasanya ada perubahan draf RAB setelah disosialisasikan melalui rapat. Perubahan tersebut biasanya berupa penambahan kegiatan jika ada kegiatan yang tidak masuk dalam anggaran awal yang telah dirumuskan dalam draf $R A B$. Setelah draf $R A B$ dirubah dan disepakati bersama kemudian draf $R A B$ disahkan oleh kepala RA, komite sekolah, dan pengurus. $R A B$ yang telah disahkan kemudian disosialisasikan melalui rapat dengan wali murid. RAB yang telah disahkan ditampilkan menggunakan LCD proyektor dan pihak RA menjelaskan setiap detail poin-poin pada $R A B$ kepada wali murid agar wali murid paham betul mengenai pembiayaan yang dibutuhkan atau dianggarkan dalam penyelenggaraan layanan PAUD di RA Masyithoh Mertasinga Cilacap.

Stakeholders yang terlibat dalam sosialisasi RAB antara lain kepala RA, pengurus, komite sekolah, dan perwakilan wali murid yang tidak masuk dalam komite sekolah. Para stakeholders turut mensukseskan, wali murid pun berkomitmen untuk memenuhi pembiayaan yang dianggarkan. Komitmen tersebut muncul karena ada kesadaran pada diri wali murid bahwa sukses atau tidaknya penyelenggaraan layanan PAUD sangat dipengaruhi oleh faktor pembiayaan.

Langkah keempat, menghitung tarif aktivitas. Kegiatan yang dilakukan pada langkah keempat yaitu: (1) menggali sumber pembiayaan PAUD untuk membiayai kegiatan PAUD; (2) menerima sumber pembiayaan PAUD untuk membiayai kegiatan PAUD; dan (3) menggunakan sumber pembiayaan PAUD untuk membiayai kegiatan PAUD.

Setelah RAB kegiatan PAUD disahkan, kemudian kepala RA Masyithoh Mertasinga Cilacap melakukan kegiatan penggalian sumber pembiayaan PAUD. Penggalian dilakukan dengan memberi buku administrasi ke semua wali murid. Kemudian kepala RA mengarahkan kepada wali murid untuk memenuhi buku administrasi tersebut secara berkala. Stakeholders yang terlibat dalam proses penggalian pembiayaan tersebut antara lain kepala RA, pengurus, dan komite sekolah. Proses pembiayaan dari berbagai sumber diterima oleh bagian administrasi sekolah atau bendahara kemudian dicatat dalam buku kas penerimaan.
Faktor pendukung yang memudahkan pihak RA Masyithoh Mertasinga Cilacap dalam melakukan penggalian pembiayaan kegiatan PAUD yaitu pengurus RA juga komite sekolah ikut membantu pihak RA dalam penggalian dana dengan memberikan himbauan-himbauan kepada wali murid agar tertib administrasi. Faktor penghambat yang menyulitkan kepala RA dalam melakukan penggalian pembiayaan kegiatan PAUD adalah ketika waktu penggalian dana dilakukan secara bersamaan dengan kegiatan penggalian dana dari lembaga lain.

Langkah kelima, menyusun laporan. Kegiatan yang dilakukan dalam langkah kelima ini antara lain: (1) menyusun laporan pembiayaan PAUD; (2) mengevaluasi laporan pembiayaan PAUD; dan (3) memberikan feedback terhadap hasil evaluasi pembiayaan PAUD.

Anggaran dikeluarkan sesuai dengan kebutuhan. Anggaran yang dikeluarkan kemudian dilaporkan penggunaannya kepada bendahara. Bahan pelaporan tersebut digunakan sebagai bahan oleh bendahara untuk membuat laporan keuangan bulanan. Proses pengeluaran biaya kegiatan PAUD dapat memenuhi semua kebutuhan pada setiap kegiatan PAUD meski terkadang ada juga beberapa kebutuhan pada suatu kegiatan yang belum bisa terpenuhi semua kebutuhannya. Biasanya ini karena ada kenaikan harga barang yang akan dibeli untuk memenuhi kebutuhan pada suatu kegiatan.

Manfaat yang didapat dari proses pengeluaran biaya kegiatan PAUD yang dapat memenuhi semua kebutuhan pada setiap kegiatan PAUD adalah kegiatan-kegiatan untuk anak-anak bisa berjalan dengan optimal sehingga target-target atau tujuan-tujuan kegiatan juga dapat dicapai secara optimal pula. Sementara itu, proses pengeluaran sudah dapat mengakomodir keinginan dan kebutuhan wali murid. Ini karena semua program yang diinginkan dan dibutuhkan oleh wali murid dapat terealisasi. Proses pengeluaran biaya kegiatan PAUD juga sudah dapat meminimalisir keluhan-keluhan dari wali murid. Indikasinya adalah minimnya keluhan-keluhan yang ditemukan oleh guru di kotak saran, wali murid juga ikut mempromosikan RA Masyithoh Mertasinga Cilacap kepada masyarakat sehingga RA di setiap tahunnya mendapatkan perolehan peserta didik barunya semakin meningkat, citra RA di masyarakat pun semakin positif, ini membuktikan bahwa masyarakat menaruh kepercayaan kepada pihak RA bahwa para guru bisa menyelenggarakan layanan PAUD secara prima. 
Proses pengeluaran biaya kegiatan PAUD di RA Masyithoh Mertasinga Cilacap sudah berlangsung sesuai dengan mekanisme. Faktor yang menjadikan proses pengeluaran berlangsung sesuai dengan mekanisme adalah karena anggaran yang dikeluarkan sesuai dengan $R A B$ yang telah disepakati bersama. Kemudian laporan penggunaan anggaran disusun setelah kegiatan selesai dilaksanakan. Stakeholdes yang menyusunnya yaitu kepala RA dan bagian administrasi RA. Kepala RA menjadi pihak yang menyampaikan laporan keuangannya.

Proses pelaporan berlangsung saat ada pertemuan wali murid melalui rapat-rapat formal yang dihadiri oleh komite sekolah dan pengurus (Sulastri, 2019). Laporan disampaikan kepada pengurus, komite dan wali murid. Pihak-pihak tersebut merespons dengan baik laporan yang disampaikan. Para stakeholders menerima dengan baik sambil meneliti arus pemasukan dan pengeluarannya. Feedback yang diberikan oleh para stakeholders kepada kepala RA adalah meminta kepada pihak RA agar konsisten dalam menyelenggarakan layanan PAUD yang sesuai dengan keinginan, kebutuhan, dan harapan wali murid. Pihak RA Masyithoh Mertasinga Cilacap menindaklanjuti feedback tersebut dengan berusaha memaksimalkan sumber daya yang ada agar semua kegiatan dapat berjalan dengan baik.

Kemudian faktor yang memudahkan kepala RA dalam melakukan pelaporan pembiayaan PAUD adalah adanya partisipasi dari wali murid, komite dan pengurus sebagai pendengar setia dan ikut mengoreksi laporan keuangan yang dibuat. Hal itu menjadikan laporan yang disusun benar-benar disusun dengan mengakomodir semua pihak yang terlibat dalam penyelenggaraan layanan PAUD. Hal yang menyulitkan dalam melakukan pelaporan pembiayaan PAUD adalah ketika terjadi kekurangan anggaran yang menyebabkan ketidaksesuaian antara rencana dengan laporan dan tentu ini menjadi hal yang tidak diharapkan untuk terjadi.

\section{PEMBAHASAN}

Tujuan yang telah ditetapkan dalam menciptakan layanan PAUD prima prima telah tercapai. Lembaga menerima banyak manfaat dari ketercapaian tersebut. Ada lima manfaat yang didapat oleh RA Masyithoh Mertasinga Cilacap. Pertama, mendapatkan dukungan materi dari masyarakat dalam penyelenggaraan layanan. Kedua, penganggaran untuk penyelenggaraan layanan yang disusun oleh wali murid menjadikannya memiliki komitmen bersama untuk memenuhi besaran anggaran yang telah ditentukannya sendiri. Ketiga, keterlibatan wali murid dalam penyusunan maupun pemenuhan anggaran telah menjadikannya terlibat dalam penyelenggaraan layanan sesuai dengan posisi dan kapasitasnya. Keempat, keterlibatan wali murid dalam menyelenggarakan layanan PAUD memunculkan rasa saling memiliki terhadap $R A$ sehingga muncul loyalitas pada mereka.

Loyalitas membuat wali murid menjadi "iklan berjalan". Rasa saling memiliki muncul karena wali murid mendapatkan kepuasan dari layanan PAUD. Kepuasan yang didapat menghasilkan citra yang positif pada lembaga (Qomariah, 2012). Kelima, layanan prima telah membuat RA mengalami pengembangan kelembagaan. Eksistensi suatu lembaga akan dipengaruhi oleh kemampuannya dalam menyelenggarakan layanan pendidikan yang prima (Cheng, 2014).

Penciptaan layanan prima dalam penyelenggaraan PAUD dilakukan dengan memenuhi keinginan dan kebutuhan serta merespons keluhan-keluhan dari wali murid. Ketiganya merupakan bagian dari orientasi pasar yang harus diperhatikan dan dipenuhi oleh organisasi (Murillo, Pimenta, Hilletofth, \& Reitsma, 2019). Pemenuhan dan respons tersebut ditunjukkan oleh pihak RA Masyithoh Mertasinga Cilacap dengan menyelenggarakan berbagai kegiatan. Pihak RA yakin ketika kegiatan-kegiatan tersebut dilaksanakan secara optimal maka keinginan, kebutuhan, dan keluhan dari wali murid akan terpenuhi. Pemenuhan tersebut dipengaruhi oleh kualitas pelayanan dan biaya yang digunakan dalam menyelenggarakan pelayanan (Adil, 2016).

Pihak RA pun menyadari bahwa untuk melaksanakan layanan kegiatan tersebut dibutuhkan biaya. Berdasarkan hal itu maka kegiatan penyusunan RAB dilakukan berdasarkan perkiraan biaya pada setiap kegiatan. Inilah yang disebut dengan metode Activity Based Costing (ABC) dalam praktek manajemen pembiayaan PAUD. Hal menarik yang didapat dari penelitian ini adalah bahwa pihak RA melibatkan wali murid yang tergabung dalam kepengurusan komite sekolah untuk merancang besaran biaya pada setiap kegiatan. Ini berarti selain wali murid memiliki kewenangan menyusun anggaran, wali murid juga memiliki kewenangan untuk mengajukan kegiatan-kegiatan PAUD. Pelibatan wali murid sebagai konsumen pendidikan dalam penyusunan anggaran dapat mendorong mereka untuk terlibat secara aktif pula dalam 
pelaksanaan kegiatan yang telah diprogramkan oleh lembaga (Manaroinsong, 2014).

Fokus utama Activity Based Costing (ABC) adalah kegiatan. Identifikasi terhadap biaya pendidikan didasari oleh identifikasi terhadap kegiatan. Dalam praktiknya, Activity Based Costing ( $\mathrm{ABC}$ ) merupakan salah satu metode manajemen pembiayaan yang menerapkan konsep-konsep akuntansi aktivitas untuk menghasilkan perhitungan harga pokok dalam layanan PAUD secara lebih akurat. Keakuratan berimplikasi pada ketersediaan anggaran yang memadai untuk melaksanakan kegiatan. Seluruh kegiatan pun dapat dilaksanakan secara efektif dan efisien karena faktor ketersediaan anggaran (Zainuddin \& Isa, 2019). Efektivitas dan efisiensi kegiatan-kegiatan dapat mengarah pada pencapaian orientasi pasar pada wali murid terkait dengan layanan PAUD yang diselenggarakan. Namun sayangnya di balik keberhasilan RA Masyithoh Mertasinga Cilacap dalam menciptakan layanan prima belum ada dukungan teknologi. Hasil penelitian menunjukkan layanan prima dapat dicapai secara optimal ketika organisasi mampu memanfaatkan teknologi (Kulathunga \& Perera, 2015)

Ada empat kunci keberhasilan dalam menciptakan layanan prima melalui praktik Activity Based Costing (ABC) di RA Masyithoh Mertasinga Cilacap. Pertama, penerapan kepemimpinan demokratis oleh kepala RA. Kepemimpinan menjadi faktor yang dapat menentukan eksistensi dan masa depan suatu lembaga pendidikan. Lembaga pendidikan akan mampu menyelenggarakan layanan yang baik dan terbaik ketika pemimpinnya memiliki karakter yang kuat, visioner, berani mengambil keputusan strategis serta memimpin dengan kepemimpinan yang demokratis (Makruf, 2017). Kuatnya kepemimpinan kepala RA akan berkontribusi terhadap peningkatan kinerja guru. Kinerja guru yang meningkat akan menghasilkan penyelenggaraan layanan PAUD yang prima (Aguswara \& Rachmadtullah, 2017).

Kedua, penguatan kompetensi guru sebagai SDM utama dalam menyelenggarakan layanan prima. Kepala RA sebagai pemimpin memberikan kesempatan kepada guru untuk melanjutkan studi S2 serta mengikuti pelatihan yang diselenggarakan secara eksternal. Sebagai seorang supervisor, pimpinan $d$ lembaga pendidikan harus mampu melayani guru untuk mengembangkan kompetensinya sehingga ia dapat menjadi guru yang profesional dan mampu menyelenggarakan kegiatan pembelajaran yang kreatif. Selain, pimpinan di lembaga pendidikan juga harus mampu memotivasi para guru untuk bekerja secara produktif sehingga setiap target pada setiap kegiatan dapat tercapai. Guru dapat melakukannya manakala memiliki kompetensi pedagogi, profesional, sosial, dan kepribadian (Machali, 2019). Kompetensi yang dimiliki oleh para guru di suatu lembaga pendidikan akan menjadikan lembaga pendidikan memiliki kapasitas atau kemampuan yang jelas dalam upaya perbaikan lembaga secara berkelanjutan (Sukaningtyas, 2017). Untuk membentuk seorang guru profesional dan berkompetensi diperlukan pembinaan yang baik kepada guru yang dilakukan oleh kepala RA.

Ketiga, kebesaran hati kepala RA dan guru untuk memposisikan diri sebagai "pelayan" bagi konsumen. Upaya yang dilakukan adalah dengan mendengarkan apa yang diinginkan, apa yang dibutuhkan, dan apa yang dikeluhkan oleh konsumen. Kemudian memenuhinya dengan melakukan upaya perbaikan berkelanjutan terhadap kegiatan-kegiatan pendidikan yang telah dilaksanakan. Upaya perbaikan berkelanjutan pada dasarnya merupakan upaya mendesain ulang kualitas layanan. dengan memperhatikan standar layanan (Wilson, Keni, \& Tan, 2019). Layanan yang berstandar itulah yang akan menghasilkan proses serta hasil pendidikan yang bermutu (Muhtifah \& Muskania, 2019). Keempat, adanya upaya dari pihak RA untuk dapat menyelenggarakan proses pembiayaan PAUD yang bermutu. Kegiatan pembiayaan PAUD dikatakan bermutu jika pengelola lembaga PAUD mengenal sumber-sumber pembiayaan dengan baik, melakukan pembukaan keuangan secara tertib, memiliki pengetahuan dan skill yang terkait dengan manajemen pembiayaan yang transparan, efisien, serta akuntabel (Soeharto, 2012).

\section{SIMPULAN DAN SARAN}

Ada lima langkah yang dilakukan untuk menciptakan layanan prima dalam penyelenggaraan PAUD melalui praktik ABC. Kelima langkah tersebut dilakukan secara sistematis. Secara garis besar langkah yang dilakukan untuk menghasilkan layanan PAUD yang prima melalui penerapan praktik $A B C$ yaitu menentukan kebutuhan konsumen, menentukan berbagai aktivitas untuk memenuhi kebutuhan konsumen, menetapkan anggaran, menggunakan anggaran sesuai dengan kebutuhan pada setiap aktivitas, serta menyusun laporan. Orang tua puas dengan 
adanya penyelenggaraan layanan PAUD yang prima.

Ada tiga yang direkomendasikan kepada peneliti, praktisi, dan pembuat kebijakan di bidang ilmu keluarga dan konsumen. Pertama, penyusunan anggaran dalam penyelenggaraan layanan pendidikan bagi masyarakat seyogyanya dilakukan secara terbuka dengan memanfaatkan aplikasi e-budgeting. Kedua, jenis kebutuhan pada setiap aktivitas yang diidentifikasi dalam Rencana Anggaran Belanja (RAB) seyogyanya ditentukan berdasarkan kebutuhan dan harapan masyarakat. Ketiga, bagi peneliti berikutnya yang hendak mengkaji tentang praktik Activity Based Costing (ABC) untuk menciptakan layanan PAUD yang prima sebaiknya menghubungkan fokus kajiannya dengan praktik kepemimpinan yang diterapkan oleh pengelola lembaga PAUD.

\section{DAFTAR PUSTAKA}

Adil, A. (2016). Pengaruh kualitas pelayanan dan biaya terhadap kepuasan dan loyalitas pasien RSUD Kota Bogor. Jurnal Aplikasi Manajemen, 14(3), 432-441. doi:https: //doi.org/10.18202/jam23026332.14.3.04

Adiyanto. (2019, Juli 21). RA berdaya saing di Cilacap [Recorder].

Aguswara, W. W., \& Rachmadtullah, R. (2017). Pengaruh gaya kepemimpinan kepala sekolah dan iklim organisasi dengan kinerja guru pendidikan anak usia dini. JPUD - Jurnal Pendidikan Usia Dini, 11(2), 369-385. doi:https://doi.org/10.21009/ JPUD.112.14

Aisyiyah, N., Hartoyo, H., \& Krisnatuti, D. (2019). Analisis perilaku komplain konsumen online shopping. Jurnal IImu Keluarga dan Konsumen, 12(3), 248-259. doi:https://doi.org/10.24156/jikk.2019.12.3. 248

Cheng, B. L. (2014). Service quality and the mediating effect of corporate image on the relationship between customer satisfaction and customer loyalty in the Malaysian Hotel Industry. Gadjah Mada International Journal of Business, 15(2), 99. doi:https://doi.org/10.22146/gamaijb.5474

Hariandja, E. S., Simatupang, T. M., Nasution, R. A., \& Larso, D. (2014). Dynamic marketing and service innovation for service excellence. Gadjah Mada International Journal of Business, 16(2), 143. /gamaijb.5461
Kulathunga, D., \& Perera, W. L. M. V. (2015). Impact of self service technology quality on customer satisfaction: A case of retail banks in Western Province in Sri Lanka. Gadjah Mada International Journal of Business, 17(1), 1. doi:https://doi.org /10.22146/gamaijb.6147

Moleong, L. J. (2012). Metodologi penelitian kualitatif. Bandung, ID: Rosda.

Machali, I. (2019). Managing quality of learning in islamic schools: An analysis of contributing factors for learning toward quality improvement in private islamic senior high schools in Yogyakarta. Jurnal Pendidikan Islam, 7(2), 317-335. doi:https://doi.org/10.14421/jpi.2018.72.31 7-335

Makruf, I. (2017). Leadership model in integrated islamic educational institutions. Jurnal Pendidikan Islam, 6(2), 331. doi:https://doi.org/10.14421/jpi.2017.62.33 $1-348$

Maryani. (2019, Agustus). Masalah dan tantangan penyelenggaraan $R A$ di Kabupaten Cilacap [Recorder].

Maryani. (2019a). Rencana anggaran belanja RA Masyithoh Mertasinga Cilacap. RA Masyithoh Mertasinga Cilacap.

Maryani. (2019b). Buku induk siswa. RA Masyithoh Mertasinga Cilacap.

Maryani. (2019, September 3). Implementasi Activity Based Costing (ABC) di RA Masyithoh Mertasinga Cilacap [Recorder].

Miswanto, M., \& Angelia, Y. R. (2017). The influence of service quality and store atmosphere on customer satisfaction. Jurnal Manajemen dan Kewirausahaan, 19(2), 106-111. doi:https://doi.org/ 10.9744/jmk.19.2.106-111

Muhtifah, L., \& Muskania, R. T. (2019). The design on quality system model of FTIK IAIN Pontianak in SNPT 2015 and QMS ISO 9001:2015. Jurnal Pendidikan Islam, 7(2), 383-404. doi:https://doi.org/10.14421 /jpi.2018.72.383-404

Mukti, Y., \& Hendrawan, D. (2018). Early education matter: The power of childparent attachment quality in predicting child's executive function. Jurnal IImu Keluarga dan Konsumen, 11(1), 74-83. doi:https://doi.org/10.24156/jikk.2018.11.1. 74

Mulyasa. (2017). Strategi pembelajaran PAUD. Bandung, ID: Rosda. 
Mulyasana, D. (2015). Pendidikan bermutu dan berdaya saing. Bandung, ID: Rosda.

Murillo, O., Pimenta, A. B., Hilletofth, M. L. P., \& Reitsma, E. (2019). Achieving market orientation through cross-functional integration. Operations and Supply Chain Management: An International Journal, 175-185. oscm0380241

Fattah, N. (2016). Standar pembiayaan pendidikan. Bandung, ID: Rosda.

Fattah, N. (2017). Manajemen pembiayaan pendidikan: Berbasis aktivitas pembelajaran. Bandung, ID: Rosda.

Fattah, N., \& Gautama, B. P. (2017). Penerapan biaya pendidikan berbasis activity-based costing dalam meningkatkan mutu pendidikan di perguruan tinggi: Studi kasus di Universitas Pendidikan Indonesia. 2(1), 19-32. doi:https://doi.org/10.17509/ mimbardik.v2i1.6020

Oji, F. (2015). Desain model manajemen pemasaran berbasis layanan jasa pendidikan pada MTs Swasta Se-Kota Semarang. Nadwa, 9(1), 69. doi:https://doi.org/10.21580/nw.2015.9.1.5 22

Pardede, E. N., Supena, A., \& Fahrurrozi, F. (2018). Hubungan kelekatan orang tua dan regulasi diri dengan kemampuan sosial anak. JPUD - Jurnal Pendidikan Usia Dini, 12(1), 37-50. doi:https://doi.org/10.21009// JPUD.121.04

Ramdhani, H. S., Daryanto, A., \& Rifin, A. (2015). Kepuasan sebagai variabel antara kualitas produk, kualitas pelayanan, dan persepsi nilai terhadap loyalitas konsumen pada restoran baru. Jurnal IImu Keluarga dan Konsumen, 8(2), 115-124. doi:https://doi.org/10.24156/jikk.2015.8.2.1 15

Rangkuti, F. (2017). Customer care excellence: Meningkatkan kinerja perusahaan melalui pelayanan prima. Jakarta, ID: Gramedia.

Risaldy, S. (2014). Manajemen pengelolaan sekolah anak usia dini. Jakarta, ID: Luxima.

Riyadi, S., Hermawan, A., \& Sumarwan, U. (2015). Kepuasan masyarakat terhadap kualitas pelayanan kantor pertanahan Kabupaten Indramayu. Jurnal IImu Keluarga dan Konsumen, 8(1), 49-58. doi:https://doi.org/10.24156/jikk.2015.8.1.4 9
Sharma, A., \& Nandi, S. (2018). A review of behavioral decision making in the newsvendor problem. Operations and Supply Chain Management: An International Journal, 200-2013. doi:https://doi.org/10.31387/oscm0350214

Simangunsong, E. (2019). Factors determining the quality management of higher education: A case study at a business school in indonesia. Jurnal Cakrawala Pendidikan, 38(2), 215-227. doi:https://doi. org/10.21831/cp.v38i2.19685

Soeharto. (2012). Pencapaian standar nasional pendidikan di sekolah menengah kejuruan Daerah Istimewa Yogyakarta. Jurnal Cakrawala Pendidikan, 1. doi:https://doi. org/10.21831/cp.v0i1.1464

Sugiyono. (2010). Metode penelitan kuantitatif, kualitatif dan $R$ \& $D$. Jakarta, ID: Alfabeta.

Sukaningtyas, D. (2017). Pengembangan kapasitas manajemen sekolah dalam membangun pemahaman visi dan misi. Jurnal Cakrawala Pendidikan, 36(2). doi:https://doi.org/10.21831/cp.v36i2.1184 4

Sukendar, A., Usman, H., \& Jabar, C. S. A. (2019). Teaching, loving, caring (asahasih-asuh) and semi-military education on character education management. Jurnal Cakrawala Pendidikan, 38(2), 292-304. doi:https://doi.org/10.21831/cp.v38i2.2445 2

Sulastri. (2019, September 11). Pelaporan kegiatan RA Masyihoh Mertasinga Cilacap [Recorder]

Supriyanto, A. (2015). Implementasi total quality management dalam sistem manajemen mutu pembelajaran di institusi pendidikan. Jurnal Cakrawala Pendidikan, 1(1). cp.v1i1.4188

Wandani, D., \& Simanjuntak, M. (2019). Kepribadian, motivasi, dan perilaku komplain berdasarkan suku. Jurnal IImu Keluarga dan Konsumen, 12(3), 236-247. doi:https://doi.org/10.24156/jikk.2019.12.3. 236

Wilson, N., Keni, K., \& Tan, P. H. P. (2019). The effect of website design quality and service quality toward repurchase intention in the e-commerce industry: A crosscontinental analysis. Gadjah Mada International Journal of Business, 21(2), $187 . \quad$ doi:https://doi.org/10.22146/ gamaijb.33665 
Yuniawan, A. (2011). Evaluasi orientasi layanan sebagai bagian dari budaya organisasi dan efeknya terhadap kinerja organisasi. Jurnal Manajemen dan Kewirausahaan, 13(1), 46-60. doi:https://doi.org/10.9744
Zainuddin, S., \& Isa, C. R. (2019). Workplace fairness, information sharing and employee performance in a budget setting: An empirical study. Gadjah Mada International Journal of Business, 21(2), $135 . \quad$ doi:https://doi.org/10.22146/ gamaijb.31133 